\title{
Accounting
}

\section{Could the minimization of opportunity prevent fraud? An empirical study in the auditors' perspective}

\author{
Sri Handayani ${ }^{*}$ and Warsito Kawedar ${ }^{a}$
}

\begin{tabular}{l} 
aAccounting Department, Universitas Dip \\
\hline C H R O N I C L E \\
\hline Article history: \\
Received: January 1, 2021 \\
Received in revised format: \\
January 23 2021 \\
Accepted: February 17, 2021 \\
Available online: \\
February 17, 2021 \\
\hline Keywords: \\
Minimization opportunity \\
Method of prevention and \\
detection fraud \\
Internal control \\
Management policy \\
Management integrity
\end{tabular}

\section{Introduction}

Fraud can be defined as intentional deception by concealing or misrepresenting information that has the consequences of endangering other people's financial interests and benefiting the perpetrator's financial interests. Meanwhile, ACFE defines fraud as an act to achieve personal gain by deliberately using the assets of employers or organizations and is carried out professionally (Atagan \& Kavak, 2017). The purpose of the perpetrator committing fraud is to obtain personal gain illegally or to obtain information that is not supposed to be and may cause harm to other parties. In the public sector, fraud has consequences that can harm state finances and damage the socio-cultural joints of society (BPKP, 2008). ACFE classifies fraud that occurs in the organization into three fraud schemes which include (1) misappropriation of assets, (2) fraudulent financial reporting, and (3) corruption. Misappropriation of assets is usually carried out by employees. Misappropriation of assets is the most common form of fraud, but it causes immaterial losses. Perpetrators of misappropriation of assets are difficult to detect by auditors when general audits are carried out. The second type of fraud is fraudulent financial statements. Financial statement manipulation is a form of fraud through misrepresentation of actual financial conditions for personal gain. Third, corruption is a type of fraud which in its implementation involves a number of schemes such as bribery and extortion, usually it involves internal parties who cooperate with outside parties. Corruption is also defined as an inducement by an individual against a power holder in an inappropriate manner to abuse authority that would be detrimental to the interest of the other parties and provide financial benefit to the perpetrator. It is often associated with bribery (Rossouw et al., 2000). ACFE (2016) reports that the most common types

\footnotetext{
* Corresponding author.

E-mail address: shandayani.undip@gmail.com (S. Handayani)
}

(C) 2021 by the authors; licensee Growing Science, Canada doi: 10.5267/j.ac.2021.2.023 
of fraud in Indonesia are corruption (71\%), assets misappropriation (31\%), and fraudulent financial statements (4\%). Even though the number of cases of fraud in the form of financial statement manipulation was the least, the largest loss incurred was \$1000,000 (ACFE, 2016).

Statement on Auditing Standards (SAS) No. 82 requires auditors to separately assess the risk of fraud (Zimbelman, 1997). Likewise, the Republic of Indonesia Supreme Audit Agency Regulation No. 1 of 2017 concerning State Financial Audit Standards, gives power to auditors to detect indications of state financial losses. Both regulations require auditors to be able to read fraud signs and design audit procedures that are more sensitive to the risk of fraud. The ability of auditors to detect fraud has received great attention from researchers, practitioners, Indonesian Legislative Assembly and policymakers. Fraud is a financial crime that is detrimental to the interests of the state. The problem of fraud can be described as an iceberg phenomenon. The number of frauds that can be detected and prevented is less than it actually occurs. Fraud prevention is the main mechanism for solving the problem of fraud. By using the antithesis framework of the Fraud Triangle Theory, this study aims to analyze the effect of fraud prevention infrastructure, namely prevention and detection methods, internal control, management policies, and management integrity, to the fraud in government agencies in auditors' perception. In the Fraud Triangle Theory, proposed by Cressey (1950), it is stated that fraud committed by a person is influenced by perceived pressure, opportunity and rationalization (Mansor \& Abdullahi, 2015). This theory provides a useful framework for organizations to analyze the level of vulnerability of the organization to fraud and unethical behavior. It also provides a way to avoid becoming a victim of fraud. An organization can focus on preventing every factor so that the organization can avoid the negative effects of fraud and prevent the development of fraud, specifically by relieve pressure, minimize opportunity and target rationalization (Suh et al., 2019; Othman et al., 2015; Petrascu \& Tieanu, 2014; Rahman \& Anwar, 2014; Ghazali et al., 2014). Relieve pressure, minimize opportunity and target rationalization can be done through the creation of methods of prevention and detection of fraud, strengthening of internal controls, creation of regulations and policies with zero tolerance for fraud and management integrity (Johansson and Carey, 2016). Relieve pressure, minimize opportunities and target rationalization are the antithesis of the Fraud Triangle Theory. Mukoro et al. (2013), Abdulrahman (2019) state that the application of forensic accounting techniques has an influence on the prevention and detection of fraud. Fraud prevention and detection methods influence the likelihood of fraud. Management policies, top from the tone, management integrity and internal control systems are thought to be tools that will influence someone's behavior to act fraudulently (Albrecht et al., 2008; Gbegi \& Adebisi, 2015; Suh et al., 2019). Management policies, top of the tone, management integrity, and an internal control system are tools that can be used to limit opportunities for fraud (Suh et al., 2019). The choice of fraud detection and prevention techniques has a strong influence on fraud (Pourhabibi et al., 2020). Anonymous channel reporting is one of the most effective tools to detect and prevent fraud (Johansson \& Carey, 2015).

\section{Theoretical framework and hypothesis development}

The Fraud Triangle Theory is based on the assumptions described in Games Theory, Agency Theory in economics literature and Stewarship Theory in the Psychology literature. These theories assume that humans will behave opportunistically to maximize their utility. The Fraud Triangle Theory by Cressey (1950) explains that every action, including fraud, has a reason. Furthermore, Cressey hypothesized that there are three factors driving a person to break trust and commit fraud. The three factors are interrelated and must exist for a person to commit fraud. These factors are 1) incentives or pressures that create a need for someone to want to commit fraud, usually in the form of non-shareable financial needs, 2) opportunities that allow the fraudster to take action fraud, and 3) the ability to rationalize, before committing fraud the fraudster looks for reasons to provide justification or to give the impression that the fraudulent behavior, he is doing is correct (Mansor \& Abdullahi, 2015; Rosefield, 1988 in Okezie, 2012). Many studies have shown that one of the biggest contributing factors that encourage someone to commit fraud is inadequate internal control, because it provides an 'opportunity' for fraudsters to commit crimes (Dorminey et al., 2010; Dorminey et al., 2012; Rodgers et al., 2015; Fullerton \& Durtschi, 2010). In order to prevent fraud, the interaction of these three supporting factors is needed, namely relieve pressure, minimize opportunity and target rationalization (Suh et al., 2019; Othman et al., 2015; Petrascu \& Tieanu, 2014; Rahman \& Anwar, 2014; Ghazali et al., 2014). Minimizing opportunity is the construct that is easiest to observe compared to the other factors. Minimize opportunity is an organizational and environmental factor that can be formed as an effort to prevent fraud. The whistleblowing system (violation reporting system) is a mechanism that can be used to prevent fraud by minimizing the opportunity for the perpetrators of fraud. The Association of Certified Fraud Examiner (ACFE) states that the whistleblowing system is an effective way to prevent fraud (Noviani \& Sambharakreshna, 2014). Whistleblowing can provide information and reports on acts of fraud. In reporting, a whistleblower hotline is required. When reporting fraud, so as not to harm victims and witnesses for acts of fraud by reporting anonymous tips. Fraud prevention and detection methods influence fraud (Gbegi \& Adebisi, 2015), the intention is that the higher the organization applies prevention and detection methods, it is hoped that it will reduce the act of fraud. Based on the description above, the formulation of the hypothesis proposed is:

$\mathrm{H}_{1}$ : Methods of prevention and detection of fraud have a negative effect on fraud. 
Internal control is one of the mechanisms that can be used to prevent fraud. Weak internal controls provide opportunities for fraud perpetrators to commit fraud. Minimizing opportunities can be done by strengthening the organization's internal controls. Shintadevi (2015) states that the effectiveness of internal control has a significant effect on the tendency of accounting fraud. On the contrary, Astarani and Angelita (2014) stated that control activities were not able to minimize the tendency of accounting fraud in the cooperatives. The control activities were not able to run effectively without the existence of policies and procedures from management to monitor the implementation of duties. The findings contained in the audit report from the Board of Audit the Republic of Indonesia in 2018 stated that the Internal Control System (SPI) in government agencies were very weak. The weaknesses of the Internal Control System include the information system for the preparation financial statement 2017 that has not been able to resolve the difference in Inter-Entity Transactions and reciprocal transactions, administration of tax receivables, inadequate control over the management of the subsidy program, and so on. So, the weakness of the Internal Control System will encourage the tendency for the occurrence of fraud.

\section{$\mathrm{H}_{2}$ : Internal control has a negative effect on fraudulent acts.}

Policies can be used to prevent fraud. In addition, management policies are used to take steps to anticipate and minimize opportunities for fraudsters to act fraudulently. Fraud can occur because of disobedience to the regulations. Shintadevi (2015) shows that compliance with accounting rules has a significant effect on unethical behavior. If compliance with accounting standards has a relationship with unethical behavior, then non-compliance with statutory policies can lead to fraudulent acts. Gbegi and Adebisi (2015) say that management policies affect the prevention and detection of fraud. Based on the description above, the formulation of the hypothesis to be tested is:

\section{$\mathrm{H}_{3}$ : Management policy has a negative effect on fraud.}

Management integrity, namely an attitude of honesty, transparency, wisdom, and responsibility to realize the quality of public trust in the organization. Management integrity must be possessed by every organization. Auditors put their trust in the integrity of management when there are reasonable beliefs that become management's reasons for making decisions (Simamora, 2002). The higher the level of management integrity, the higher the confidence of auditors and the public. Gbegi and Adebisi (2015) state that management integrity has a significant effect in preventing fraud. There is a positive relationship between integrity and fraud prevention. In auditors' perception, the higher integrity tends to easier the auditor will be to detect and prevent fraud. If the integrity is low and the pressure faced is high, the opportunity to commit fraud will be even higher. (Prawira et al., 2014).

\section{$\mathrm{H}_{4}$ : Management integrity has a negative effect on fraud.}

\section{Research methods}

\subsection{Research Samples and Data}

The study population was government auditors who worked at the State Audit Agency (BPK), the Development and Finance Supervisory Agency (BPKP), and the Inspectorate. Data collection was carried out by means of a questionnaire. Questionnaires were distributed to participants who took part in "Risk Management Training" held in the cities of Semarang and Purbalingga. The training participants come from government external auditors working at the State Audit Agency and the Development and Finance Supervisory Agency. Participants also come from local government internal auditors who work as the Government Internal Audit Apparatus (APIP). Respondents were given time to fill out a questionnaire for 30 minutes.

\subsection{Operational Variables and Variable Measurement}

The fraud as the dependent variable (Y) is the aberrant activities undertaken in the workplace to gain advantage for himself. ACFE classifies fraud into three categories, namely misappropriation of assets, fraudulent financial reporting, and corruption. Methods of prevention and detection (X1). Prevention of fraud is the first action to stop the act of fraud, but if it fails, then the detection of fraud is immediately carried out (Othman, et.al., 2015). Indicators of fraud prevention and detection methods adopt Gbegi and Adebisi (2015) and ACFE instruments such as surprise audits, job rotations, employee consultation programs, installation of digital surveillance tools, whistleblowing, supervision by internal government auditors, regular audits, mandatory vacations, password protection on data / computers, training to overcome fraud, code of ethics, transactions using non-cash, and giving rewards and punishments. Internal control activities (X2) are a comprehensive and integrated activities that is carried out continuously by the management and all employees to provide reasonable assurance in the achievement of organizational goals through effective and efficient activities, reliability of financial reporting, safeguarding assets, and compliance with laws and regulations (article 1 PP number 80 of 2008). Internal control variables are measured by 17 indicators consisting of review activities, human resource development, physical asset control, authorization, recording, data access, accountability, and 
documentation (PP number 80 of 2008). Each internal control indicator is measured on a 5-point interval scale, a score of 1 indicates very low and a score of 5 indicates very high.

Third, management policy (X3). Each organization will create and implement management policies to reduce acts of fraud. Government agencies develop policies to reduce fraud by adopting the Fraud Control Plan (FCP). FCP is defined as a series of programs designed to prevent, to detect and to facilitate disclosure of activities that indicate fraud. Management policy indicators in this study use the attributes of the FCP (BPKP, 2013). The attributes of management policy derived from the FCP consist of anti-fraud policy, accountability structure, risk assessment, employee's awareness, customer and public awareness, fraud reporting system, mechanism of protection to whistleblower, disclosure to adequate information to external parties, investigative procedures, and standards of behavior and discipline. Integrity is one of the methods that can be used by the leader of government agencies to create and maintain a control environment that creates positive and conducive behavior in the context of implementing the Internal Control System in the workplace (article 4 of PP number 60 of 2008). Management integrity is measured by 9 indicators compiled from the provisions of Article 5 of Government Regulation Number 60 of 2008 which include rules of conduct, exemplary, enforcement of disciplinary action, intervention against the neglect behavior of internal control, and elimination of unethical behavior. Each research variable was measured by a 5-point interval scale, with a score of 1 indicating very low and a score of 5 indicating very high.

\section{Method of Analysis}

Descriptive statistical analysis is used to explain the conditions that are the subject of research based on the collected data so that it can provide an overview of the object under study. Hypothesis testing uses Structural Equation Modeling Partial Least Square (SEM-PLS). The research variables are confirmatory with reflective indicators. The testing stage is the evaluation of the measurement model (outer model) and evaluation of the structural model (inner model). Outer model is said to be good if it meets convergent validity, discriminant validity, and reliability. The evaluation of the structural model (inner model) aims to predict the relationship between variables by knowing the coefficient of determination (R-Square) and the value of t-statistics with a significance level of $5 \%$.

\subsection{Distribution of the Questionnaire}

Data collection was carried out by means of a questionnaire distributed to risk management training participants in the cities of Semarang and Purbalingga. The training participants come from government external auditors and the Government Internal Audit Apparatus (APIP). Respondents were given time to fill out a questionnaire for 30 minutes. The number of questionnaires distributed was 93 auditors and 93 questionnaires returned (100.00\%). However, there were 14 (15.05\%) questionnaires that could not be used for hypothesis testing because the questionnaire was not completely filled out. Thus, the questionnaires that can be used for hypothesis testing are 79 or $84.95 \%$. The following is an illustration of the questionnaire response rate presented in Table 1 .

\section{Table 1}

The Number of Questionnaire

\begin{tabular}{llll}
\hline No & Information & Frequency & Percentage \\
\hline 1. & Distributed Questionnaire & 93 & $100,00 \%$ \\
2. & The number of returned questionnaires & 93 & $100,00 \%$ \\
3. & The number of incomplete questionnaires & 14 & $15,05 \%$ \\
4. & The number of questionnaires that can be tested & 79 & $84,95 \%$ \\
\hline
\end{tabular}

Table 2 shows the origin of the respondents whose questionnaires can be used for hypothesis testing are 2 BPK (2.53\%), 6 BPKP (7.60\%), and the provincial / regency inspectorate office as many as 89 people $(89.87 \%)$.

\section{Table 2}

Distribution of Respondent

\begin{tabular}{llll}
\hline No & Institution & Frequency & $\%$ \\
\hline 1. & BPK & 2 & 2,53 \\
2. & BPKP & 6 & 7,60 \\
3. & Inspectorate Office & 71 & 89,87 \\
\hline & Total & 79 & 100,00 \\
\hline
\end{tabular}

Table 3 shows an overview of respondents grouped by gender, age, education, work experience in conducting audits, and length of work in the agency. Respondents were divided into 27 (34.18\%) men and 52 (65.82\%) women. Based on age, the respondents 
aged between 25-35 years were 30 (37.97\%) people and those over 35 years old were 49 (62.03\%) people. The education level of the respondents was as many as 5 people have diploma degrees or about $6.33 \%, 45$ people have bachelor degrees $(56.96 \%)$ and 29 persons have master degrees or about $37.71 \%$ of the total respondents. Based on audit experience, the number of respondents conducting audits less than 5 times was 11 people (13.92\%) and 63 people have conducted audits more than 15 times $(79.75 \%)$. Respondents who have work experience $<5$ years are 26 people $(32.91 \%)$ and over 21 years are 12 people $(15.19 \%)$.

Table 3

Description of Respondent

\begin{tabular}{llll}
\hline Description & Criteria & Number & Percentage \\
\hline Gender & Male & 27 & 34.18 \\
& Female & 52 & 65.82 \\
\hline Age & $25-35$ & 30 & 37.97 \\
& $>35$ & 49 & 62.03 \\
\hline Education & Diploma & 5 & 6.33 \\
& Bachelor & 45 & 56.96 \\
& Master & 29 & 37.71 \\
\hline Work experience as an auditor & $<5$ times & 11 & 13.92 \\
& $5-10$ times & 1 & 1.27 \\
& $11-15$ times & 4 & 5.06 \\
\hline Length of Work & $>15$ times & 63 & 79.75 \\
& $\leq 5$ years & 26 & 32.91 \\
& $6-10$ years & 20 & 25.32 \\
& $11-15$ years & 12 & 15.19 \\
& $16-20$ years & 9 & 11.39 \\
\hline
\end{tabular}

\subsection{Descriptive Statistic Analysis}

Descriptive statistical analysis was carried out by looking at the theoretical and actual range, minimum and maximum values, theoretical and actual mean, and standard deviation from each research variable. The results of the analysis are presented in Table 4. The actual mean of fraud variable was 30.82 and the theoretical mean was 45 . The actual mean is lower than the theoretical mean, so it can be interpreted that the respondents' perception of the auditees' commitment to fraud prevention was still low. The actual average value of the prevention and detection method variable was 9.24 and the theoretical average value was 9. Because the actual average value is higher than the theoretical mean, it can be concluded that in the respondents' perception of the prevention and detection methods employed by the auditee was sufficiently high. The actual mean of the internal control variable is 24.42 and the theoretical mean is 24 . Internal control variable has actual mean higher than theoretical mean. It means that the auditors who are respondents of this study have a perception of internal control carried out by the auditee is at marginal value. In this research, the management policy variable has an actual mean of 26.04 and a theoretical mean of 24. The figure has a meaning that in the perception of auditors who are respondents of this research management policies carried out by the auditee were quite high. The variable of the management integrity has actual mean value of 14.29 and the theoretical mean value of 15 , which means that the auditors' perception of management integrity implemented by the auditee is still low.

\section{Table 4}

Result of Descriptive Statistic Analysis

\begin{tabular}{lllllll}
\hline & N & Range & & Mean & & Std. Deviation \\
\cline { 3 - 7 } & & Theoretical & Actual & Theoretical & Actual & \\
\hline Fraud & 79 & $15-60$ & $15-58$ & 45 & 30.82 & 9.87 \\
Prevention and Detection Method (MPP) & 79 & $3-15$ & $3-15$ & 9 & 9.24 & 2.48 \\
Internal Control (PI) & 79 & $8-40$ & $15-40$ & 24 & 24.42 & 5.23 \\
Management Policy (KM) & 79 & $8-40$ & $13-41$ & 24 & 26.04 & 6.24 \\
Integrity of Management (IM) & 79 & $5-25$ & $5-22$ & 15 & 14.29 & 3.41 \\
\hline
\end{tabular}

\section{Results and discussion}

The first step taken before hypothesis testing is to test the quality of the data. Data quality testing aims to examine the data reliability and validity of the construct. Data quality and hypothesis testing is done by using the Structural Equation ModelPartial Least Square (SEM-PLS). 
Evaluation of the measurement model is intended to measure the closeness degree of the correlation between indicators and latent variables. The value of the closeness degree of this correlation becomes the basis to measure the validity and reliability of the research model. Based on the result of data testing by using SEM-PLS, measurement of construct validity is done by looking at the outer loading score and convergent validity. If the value of Cross-Loading score $>0,7$, it can be concluded that the measuring instrument of the variable has a good construct validity.

\section{Table 5}

Cross Loadings Score

\begin{tabular}{|c|c|c|c|c|c|}
\hline Description & Variable & & & & \\
\hline Indicator & TK & MPP & $\mathrm{PI}$ & KM & IM \\
\hline TK6 & 0.711 & & & & \\
\hline TK8 & 0.750 & & & & \\
\hline TK9 & 0.807 & & & & \\
\hline TK10 & 0.836 & & & & \\
\hline TK11 & 0.714 & & & & \\
\hline TK12 & 0.770 & & & & \\
\hline TK13 & 0.713 & & & & \\
\hline TK18 & 0.822 & & & & \\
\hline TK19 & 0.772 & & & & \\
\hline TK23 & 0.822 & & & & \\
\hline TK24 & 0.759 & & & & \\
\hline TK25 & 0.812 & & & & \\
\hline TK26 & 0.814 & & & & \\
\hline TK27 & 0.782 & & & & \\
\hline TK28 & 0.837 & & & & \\
\hline MPP1 & & 0.950 & & & \\
\hline MPP2 & & 0.899 & & & \\
\hline MPP6 & & 0.772 & & & \\
\hline PI3 & & & 0.811 & & \\
\hline PI4 & & & 0.763 & & \\
\hline PI6 & & & 0.726 & & \\
\hline PI10 & & & 0.813 & & \\
\hline PI14 & & & 0.807 & & \\
\hline PI15 & & & 0.835 & & \\
\hline PI16 & & & 0.847 & & \\
\hline PI17 & & & 0.863 & & \\
\hline KM1 & & & & 0.787 & \\
\hline KM3 & & & & 0.878 & \\
\hline KM4 & & & & 0.848 & \\
\hline KM5 & & & & 0.798 & \\
\hline KM6 & & & & 0.858 & \\
\hline KM7 & & & & 0.857 & \\
\hline KM8 & & & & 0.794 & \\
\hline KM9 & & & & 0.842 & \\
\hline IM2 & & & & & 0.805 \\
\hline IM3 & & & & & 0.779 \\
\hline IM4 & & & & & 0.935 \\
\hline IM5 & & & & & 0.827 \\
\hline IM6 & & & & & 0.781 \\
\hline
\end{tabular}

Based on the result of data analysis, as shown in table 5, there are many indicators that have cross loading scores below 0.7 . The next step, to improve the validity construct, the indicators that have cross loading score $<0,7$ will be eliminated and will be retested for the data validity and reliability. The results of retested data show that all indicators have a cross loading score $>0.7$. So, it can be concluded that all indicators in all the variables met the construct validity requirements.

Evaluation of the variable validity can be measured based on convergent validity. The convergent validity value can be seen from the Average Variance Extracted (AVE) and communality value. Table 6 presents the AVE and communality values for each variable with a value greater than 0.5 so that these variables meet convergent validity.

Measurement of variable reliability was performed using Cronbach's alpha and composite reliability. Table 6 shows the Cronbach's Alpha value and Composite Reliability value for all of the research variables $>0.7$ The result of this analysis can illustrate that these research variables meet the requirements regarding data reliability. 
Table 6

The Result of Validity and Reliability Test

\begin{tabular}{|c|c|c|c|}
\hline Variable & Cronbach's Alpha & Composite Reliability & AVE \\
\hline Fraud & 0.954 & 0.960 & 0.613 \\
\hline Prevention and Detection Method (MPP) & 0.853 & 0.909 & 0.770 \\
\hline Internal Control (PI) & 0.928 & 0.938 & 0.656 \\
\hline Management Policy (KM) & 0.940 & 0.948 & 0.695 \\
\hline Integrity of Management (IM) & 0.893 & 0.916 & 0.686 \\
\hline
\end{tabular}

\subsection{Structural Model Testing (Inner Model)}

Inner model testing is carried out to account the closeness of the relationship among variables studied. Decision making to explain the closeness relationship among the research variables is based on the $\mathrm{R}^{2}$ value, the significance value, and the direction of the coefficient variables. The $\mathrm{R}^{2}$ value from the results of the research data processing shows 0.238 which means $23.8 \%$ of the variants of the indigenous variable, fraud, can be explained by the variants of four exogenous variables, namely the Method of Prevention and Detection of Fraud (MPP), Internal Control (PI), Management Policy (KM), and Management Integrity (IM). Decision to accept or reject the research hypothesis is based on the significance value of the relationship between exogenous latent and endogenous variables to wit the p-value and direction of the variables of coefficient. The hypothesis is supported if the $p$-value is $\leq 0.05$ and the $t$-statistics value is $\geq 1.96$. The results of hypothesis testing based on the evaluation of the structural model can be seen in Table 7 .

\section{Table 7}

Result of Hypothesis Testing

\begin{tabular}{lllll}
\hline Hypothesis & Original Sample $(\boldsymbol{O})$ & $\begin{array}{l}\text { Sample Mean } \\
(\boldsymbol{M})\end{array}$ & $\begin{array}{l}\text { Standard Deviation } \\
(\text { STDEV })\end{array}$ & $\begin{array}{l}\text { Statistics } \text {-value } \\
(\boldsymbol{O} / \boldsymbol{S T D E V} \mid)\end{array}$ \\
\hline MPP $\rightarrow$ TK & 0.433 & 0.420 & 0.120 & 3.612 \\
PI $\rightarrow$ TK & -0.358 & -0.349 & 0.112 & 3.187 \\
KM $\rightarrow$ TK & -0.272 & -0.229 & 0.171 & 1.590 \\
IM $\rightarrow$ TK & 0.172 & 0.114 & 0.110 & 1.561 \\
\hline
\end{tabular}

The first hypothesis (H1) states that prevention and detection methods have a negative effect on fraud. Table 7 shows the statistical t-value of the method of prevention and detection to fraud of 3,612 (above the value of 1.96) with a positive coefficient variable direction, while the hypothesis requires a negative coefficient direction. Thus, H1 is rejected. The results of this study are not in line with the research of Gbegi and Adebisi (2015) proving that prevention and detection methods have a positive effect on fraud. The closeness of the relationship between prevention and detection methods and fraud is low (Table 4) and rvalue is positive (see Table 5), which means that an increase in prevention and detection methods is followed by an increase in fraud. Increasingly sophisticated fraud prevention and detection methods will make people more creative to create an opportunity and method to commit fraud. Based on the result of descriptive statistical analysis, the implementation of fraud prevention and detection methods in the public sector is more emphasized on the enforcement of the code of ethics (average $=$ 3.57). Furthermore, the implementation of fraud prevention and detection methods in the public sector are bank reconciliation (average $=3.55$ ), and routine audits by internal and external auditors (average $=3.53$ ) compared to surveillance with technology $(m e a n=2.92)$. The technology to prevent fraud, which is widely used in government agencies, is through protecting confidential documents with a password (mean = 3.50). Meanwhile, according to the Association of Certified Fraud Examiner (ACFE) and the Global Economic Crime Survey (GECS) in Noviani and Sambharakreshna (2014), it is stated that the whistleblowing system is an effective way to prevent fraud. Prevention of fraud is the first action to stop acts of fraud that will occur. When fraud prevention has failed, the next step is to detect fraud because identifying fraud must be done as soon as possible (Bolton and Hands, 2002) in Othman et al. (2015). Prevention of fraudulent acts that will occur will be easier to do than when cheating has occurred (Amrizal, 2004). In addition, the costs needed to prevent fraud are less than the losses that must be borne. Therefore, an organization is required to implement an effective fraud prevention method because it can reduce the chance that fraud will occur (Bierstaker et al., 2006). A summary of the mechanism of prevention and detection methods that can affect fraud is in Fig. 1.

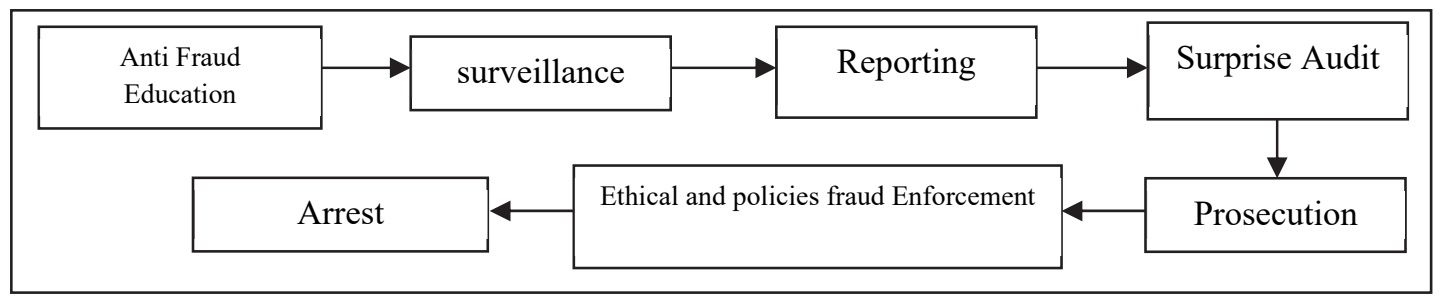

Fig. 1. Detection and Prevention Fraud Mechanisms 
The first step to prevent fraud is to provide anti-fraud education to heads of regional and civil servants. This program aims to increase awareness of the heads of regional and civil servants against the dangers of fraud and to reduce fraud. Then carried out monitoring of suspicious activities and unethical behavior. Supervision of fraud can be carried out by means of job rotation, supervision by internal auditors, digital monitoring, providing passwords on important documents, employee consultation programs to find out and monitor employee character, or by bank reconciliation, transacting through non-cash or by routine audits for aware of irregularities or not.

If during supervision there are signs of findings of fraud (red flags), reporting of such fraudulent acts can be carried out through hotline services provided by auditing agencies such as the Corruption Eradication Commission (KPK) and government auditors' offices. In detecting fraudulent acts, namely by reporting complaints of fraud from whistleblowing. In order to protect the reporter from things that endanger the reporter, through anonymous tips (not mentioning the identity of the reporter). In addition, detecting acts of fraud is also carried out by surprise audits (without providing information to be audited) of the organization concerned. After it is known that there is an indication of fraud and it is known who the perpetrator of the fraud is, then prosecution can be carried out by law enforcers with various evidences and the results of an investigative audit.

In enforcing ethics and fraud policies, agencies must create a code of ethics and determine in advance what will be done if an act of fraud occurs; in particular, what penalties will be imposed on each type of fraudulent act and degree of cheating. Then the entity will need to ensure to monitor and follow up with the provision of penalties for the perpetrators of fraud (Singleton, 2010) as well as the awarding of acts carried out by whistleblowing. The last step after an investigation is to catch the perpetrator of fraud.

\subsection{The Effect of Internal Control to Fraud}

The second hypothesis (H2) states that internal control has a negative effect on fraud. Table 7 shows that the statistical t-value is 3.187 ( $>1.96$ ) with a coefficient of -0.358 (negative coefficient). Thus, H2 is accepted. So, it can be concluded that internal control has a significant and negative effect on fraud. In other words, the stronger the internal control activity, the lower the fraud. The results of this study are consistent with research by Prawira, et.al. (2014) internal control has a negative effect on public sector fraud in Central Java Province. These results are also consistent with studies conducted by Seetharam, Senthilvelmurugan, and Periyanayagam (2004) as well as a survey conducted by PwC (2012) on the public sector in New Zealand in Othman, et.al. (2015) which states that strong internal control is the most effective fraud prevention and detection instrument. The Internal Control System (SPI) according to Government Regulation Number 60 of 2008 is defined as an integral process of actions and activities carried out continuously by the leadership and all employees to provide adequate confidence in the achievement of organizational goals through effective and efficient activities, reliability of financial reporting, safeguarding state assets, and compliance with laws and regulations. Based on the results of this study, internal control has been shown to be able to decrease fraud in government agencies. Implementation of internal control in government agencies is carried out through the formation of a quality assurance team or quality control group, one of whose tasks are to develop quality standards, develop various manuals and work standards; including in the field of financial and asset governance, as well as making an annual Government Internal Control System (SPIP) report.

Apart from that, a government agency was formed specifically to handle and act as treasurer for financial revenue and expenditure, management of the accounting system, procurement of goods, asset management, and a team that specialized in internal audit. Human resources (HR) assigned to all of government units must meet the predetermined qualifications / certifications and requirements. In carrying out their duties, all units / components of internal control are aimed at achieving: 1) effectiveness and efficiency of the organization's operations, 2) reliability of financial reporting, and 3) conformity with applicable laws and regulations.

FCP is designed to manage the risks that will arise from acts of fraud. The plan is integrated into existing risk management in the organization and is supported by documents for the management of fraud at the strategic, tactical and operational levels of the organization (AG, 2011) cited by Kummer et al. (2015). The FCP has a function in preventing and detecting fraudulent acts (Fig. 2). The application of the FCP to prevent acts of fraud is based on strong standards of behavior supported by anti-fraud policies and risk assessments. In addition, to detect indications of fraud, a community awareness and reporting system is required. Community awareness (awareness from within and outside the organization against acts of fraud) which includes concern for employees, concern for customers and society, as well as protection for whistleblowers. The existence of shared awareness in dealing with fraudulent actions can make it easier to detect fraudulent acts. Reporting system is a procedure in dealing with fraud which includes a clear accountability structure, investigative procedures, and external disclosure. The establishment of a clear fraud reporting system aims to facilitate disclosure and reporting when fraudulent acts are detected. In order for management policies to run effectively in the midst of management of an agency that can change and change, policies concerning anti-fraud need to be revised and adjusted to the needs and demands of the situation (Kuntadi, 2015). 


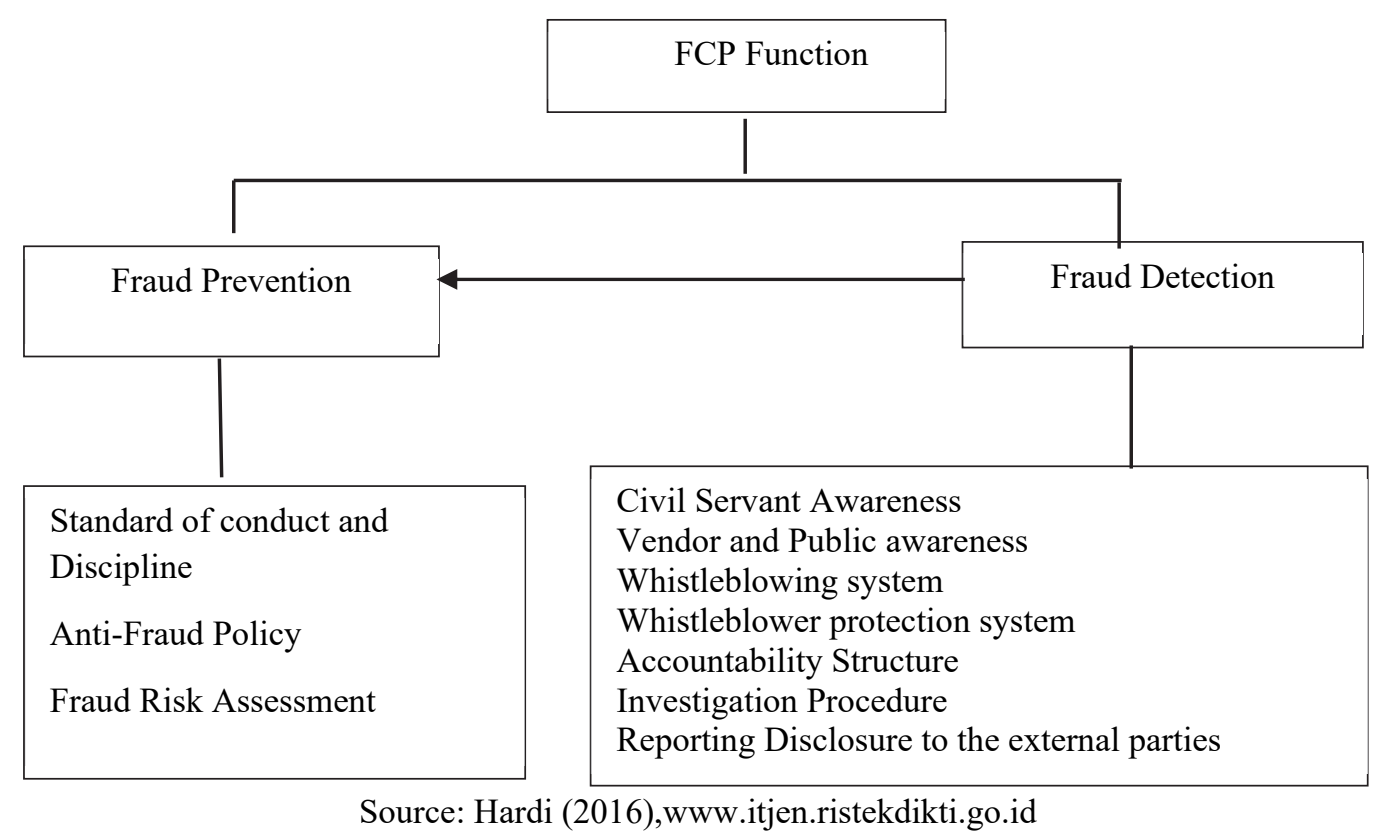

Fig. 2. FCP Function in Detection and Prevention Fraud

\subsection{The Effect of Management Integrity on Fraud}

From Table 7, it is obtained that the $t$ value of the management integrity variable is -1.386 with a probability (sig) of 0.168 . The $t$ value is smaller than $t$ table (1.655) and the significance value is greater than 0.05 . Based on the results of partial $t$, the variable management integrity partially has no effect on fraud. So, it can be concluded that the null hypothesis is accepted, while the alternative hypothesis $(\mathrm{H} 4)$ is rejected. Based on the results of the regression test, it can be seen that the integrity of management has no effect on fraud. According to research data in table 5, on average there are still government agencies that do not have management integrity in accordance with Government Regulation Number 60 of 2008 (average total score $=2.83$ ). If seen from the correlation test (table 5), management integrity has an $r$ value of -0.058 , which means that the lower the management integrity, the higher the fraud. The results of the correlation test indicate that management integrity has a very low relationship with fraud, however, based on the results of the regression test, it shows that management integrity has no effect on fraud. Albrecht's theory suggests that the personal integrity factor on the fraud scale refers to the code of ethics that is owned by each individual. Based on the fraud scale in Albrecht's theory, if the integrity is low when under pressure and the opportunity to commit fraud is high, it can cause fraud to be higher (Prawira et al., 2014). Meanwhile, according to Gbegi and Adebisi (2015) fraud in the public sector is high, one of which is due to low management integrity. The results of this study are inconsistent with the research conducted by Gbegi and Adebisi (2015) which proves that management integrity affects fraud.

\section{Conclusions, Limitations and Research Suggestions}

The results of this study indicate that internal control is one of the factors that can minimize opportunities to prevent fraud. If the effectiveness of the internal control system is higher, the opportunity for the perpetrator to commit fraud will be lower. The surprising finding from this study is that the method of preventing and detecting fraudulent acts is not able to minimize the opportunity for the fraudster. If the methods of detection and prevention of fraud become more sophisticated, the fraudster will be more creative in creating fraud methods. In the auditor's perception, the use of technology for prevention and detection is increasingly making actors more creative in expanding opportunities for fraudulent acts including utilizing window dressing in committing fraud. The disproportionate distribution of the questionnaire to the auditors of BPK, BPKP and IG is one of the reasons that the results of this research cannot reflect the perceptions of each party proportionally. In subsequent studies, the distribution of questionnaires to each party should be considered.

\section{References}

Abdulrahman, S. (2019). Forensic accounting and fraud prevention in Nigerian public sector: A conceptual paper. International Journal of Accounting \& Finance Review, 4(2), 13-21.

Albrecht, W. S., Albrecht, C., \& Albrecht, C. C. (2008). Current trends in fraud and its detection. Information Security Journal: a Global Perspective, 17(1), 2-12. 
Association of Certified Fraud Examiniers, 2016, Report to the Nation (RTTN), USA.

Astarani, J., \& Angelita, A. (2014). Analisis Pengaruh Peranan Badan Pengawas, Aktivitas Pengendalian, dan Sistem Kompensasi Terhadap Kecurangan Akuntansi (Studi Pada Koperasi di Kota Pontianak). Jurnal Audit dan Akuntansi Fakultas Ekonomi Universitas Tanjungpura, 3(2), 43-64.

Atağan, G., \& Kavak, A. (2017). Relationship between fraud auditing and forensic accounting. International Journal of Contemporary Economics \& Administrative Sciences, 7, 194-223

Bierstaker, J. L., Brody, R. G., \& Pacini, C. (2006). Accountants' perceptions regarding fraud detection and prevention methods. Managerial Auditing Journal, 21(5), 520-535.

Dorminey, J. W., Fleming, A. S., Kranacher, M. J., \& Riley Jr, R. A. (2010). Beyond the fraud triangle. The CPA Journal, 80(7), 17.

Dorminey, J. W., Fleming, A. S., Kranacher, M. J., \& Riley Jr, R. A. (2012). Financial fraud. The CPA Journal, 82(6), 61.

Fullerton, R. R., \& Durtschi, C. (2010). The Effect of Professional Skepticism on The Fraud Detection Skills of Internal Auditors. Utah State University Working Paper.

Gbegi, D. O., \& Adebisi, J. F. (2015). Analysis of fraud detection and prevention strategies in the Nigerian public sector. Journal of Good Governance and Sustainable Development in Africa (JGGSDA), 2(4), 109-128.

Ghazali, M. Z., Rahim, M. S., Ali, A., \& Abidin, S. (2014). A preliminary study on fraud prevention and detection at the state and local government entities in Malaysia. Procedia-Social and Behavioral Sciences, 164, 437-444.

Ghozali, I. (2013). Aplikasi Analisis Multivariate dengan Program IBM SPSS 21. Semarang: BPFE Undip.

Johansson, E., \& Carey, P. (2016). Detecting fraud: The role of the anonymous reporting channel. Journal of business ethics, 139(2), 391-409.

Kummer, T. F., Singh, K., \& Best, P. (2015). The effectiveness of fraud detection instruments in not-for-profit organizations. Managerial Auditing Journal, 30(4/50), 435 - 455.

Mansor, N., \& Abdullahi, R. (2015). Fraud triangle theory and fraud diamond theory. Understanding the convergent and divergent for future research. International Journal of Academic Research in Accounting, Finance and Management Science, 1, 38-45.

Mukoro, D. O., Yamusa, O., \& Faboyede, O. S. (2013). The Role Of Forensic Accounting In Fraud Detection And National Security. B VIMSR's Journal of Management Research, 5(1), 40-47.

Noviani, D. P., \& Sambharakreshna, Y. (2014). Pencegahan kecurangan dalam organisasi pemerintahan. Journal of Auditing, Finance, and Forensic Accounting, 2(2), 61-70.

Okezie, A. (2012). An analysis of fraud in Nigerian banks. American Charter of Economics and Finance, 1(2), 60-73.

Othman, R., Aris, N. A., Mardziyah, A., Zainan, N., \& Amin, N. M. (2015). Fraud detection and prevention methods in the Malaysian public sector: Accountants' and internal auditors' perceptions. Procedia Economics and Finance, $28,59-67$.

Petraşcu, D., \& Tieanu, A. (2014). The role of internal audit in fraud prevention and detection. Procedia Economics and Finance, 16, 489-497.

Prawira, I. M. D., Herawati, N. T., AK, S., Darmawan, N. A. S., \& SE, A. (2014). Pengaruh moralitas individu, asimetri informasi dan efektivitas pengendalian internal terhadap kecenderungan kecurangan (fraud) akuntansi (Studi empiris pada Badan Usaha Milik Daerah kabupaten Buleleng). JIMAT (Jurnal Ilmiah Mahasiswa Akuntansi) Undiksha, 2(1).

Rahman, R. A., \& Anwar, I. S. K. (2014). Effectiveness of fraud prevention and detection techniques in Malaysian Islamic banks. Procedia-Social and Behavioral Sciences, 145, 97-102.

Rodgers, W., Söderbom, A., \& Guiral, A. (2015). Corporate social responsibility enhanced control systems reducing the likelihood of fraud. Journal of Business Ethics, 131(4), 871-882.

Shintadevi, P. F. (2015). Pengaruh keefektifan pengendalian internal, ketaatan aturan akuntansi dan kesesuaian kompensasi terhadap kecenderungan kecurangan akuntansi dengan perilaku tidak etis sebagai variabel intervening. Nominal: Barometer Riset Akuntansi dan Manajemen, 4(2), 111-126.

Simamora, H. (2002). Auditing.Yogyakarta: UPP AMP YKPN.

Suh, J. B., Nicolaides, R., \& Trafford, R. (2019). The effects of reducing opportunity and fraud risk factors on the occurrence of occupational fraud in financial institutions. International Journal of Law, Crime and Justice, 56, 79-88.

Transparency International, 2015. The Corruption Index Perception. Berlin. Tersedia di www.transparency.org.

Zimbelman, M. F. (1997). The effects of SAS No. 82 on auditors' attention to fraud risk factors and audit planning decisions. Journal of Accounting Research, 35, 75-97.

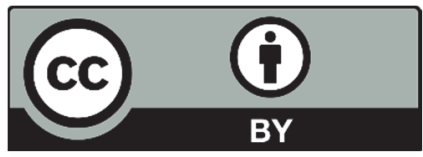

(C) 2021 by the authors; licensee Growing Science, Canada. This is an open access article distributed under the terms and conditions of the Creative Commons Attribution (CC-BY) license (http://creativecommons.org/licenses/by/4.0/). 